\title{
Evolution of small-scale flow barriers in German Rotliegend siliciclastics
}

\author{
BENJAMIN BUSCH ${ }^{1 *}$, REBECCA WINKLER $^{1}, \mathrm{KEYVAN} \mathrm{OSIVANDI}^{2}$, GEORG NOVER $^{3}$, \\ ALEXANDRA AMANN-HILDENBRAND ${ }^{4} \&$ CHRISTOPH HILGERS $^{1}$ \\ ${ }^{1}$ Institute of Reservoir-Petrology, EMR Energy and Mineral Resources Group, \\ RWTH Aachen University, Wuellnerstraße 2, 52062 Aachen, Germany \\ ${ }^{2}$ RWE DEA AG, Hamburg, Ueberseering 40, 22297 Hamburg, Germany \\ ${ }^{3}$ Steinmann-Institute of Geology, Mineralogy und Palaeontology, University Bonn, \\ Meckenheimer Allee 169, 53115 Bonn, Germany \\ ${ }^{4}$ Institute of Geology and Geochemistry of Petroleum and Coal, EMR Energy and Mineral \\ Resources Group, RWTH Aachen University, Lochnerstraße 4-20 (House B), \\ 52062 Aachen, Germany \\ *Corresponding author (e-mail: Benjamin.Busch@emr.rwth-aachen.de)
}

\begin{abstract}
Many siliciclastic reservoirs contain millimetre scale diagenetic and structural phe nomena affecting fluid flow. We identified three major types of small scale flow barriers in a clastic Rotliegend hydrocarbon reservoir: cataclastic deformation bands; dissolution seams; and bedding parallel cementation. Deformation bands of various orientations were analysed on resistivity image logs and in core material. They are mainly conjugates, and can be used to validate seismically observable faults and infer subseismic faults. Bedding parallel dissolution seams are related to compaction and post date at least one set of deformation bands. Bedding parallel cementation is accumulated in coarser grained layers and depends on the amount of clay coatings.

Apparent permeability data related to petrographical image interpretation visualizes the impact of flow barriers on reservoir heterogeneity. Transmissibility multiplier calculations indicate the small efficiency of the studied deformation bands on flow properties in the reservoir. Deformation bands reduce the host rock permeability by a maximum of two orders of magnitude. However, host rock anisotropies are inferred to reduce the permeability by a maximum of four orders of magnitude. The relative timing of these flow barriers, as well as the assessment of reservoir heterogeneities, are the basis for state of the art reservoir prediction modelling.
\end{abstract}

Deformation bands are zones of localized deforma tion in granular media, and are frequently reported from siliciclastic rocks and limestones (e.g. Anto nellini \& Aydin 1995; Fossen et al. 2007; Legler \& Marchel 2008; Wennberg et al. 2013). Generally, three end members of deformation bands are kine matically classified as shear bands, compaction bands and dilation bands (Fossen et al. 2007). The orientation of the localization plane with respect to the principal stress orientation and the deforma tion band type differs for these three end members (Bésuelle \& Rudnicki 2004, fig. 5.16). Shear local ization forms at low effective stresses, compaction at higher effective stresses and dilation is linked to decreasing effective pressures (Wong et al. 1997; Bésuelle \& Rudnicki 2004). Low porosity and small grain size exert an influence on the phys ical process of strain localization and will result in an increased magnitude of the compactive yield strength (Wong et al. 1997; David et al. 2001; Schultz et al. 2010).

The wide range of varying microstructures in deformation bands is reflected by the diverse termi nology, addressing the mineralogical composition (e.g. the incorporation of clay minerals into the deformation band by shearing results in phyllosili cate bands), the kinematic or physical processes of formation (e.g. dilational deformation bands, cata clastic deformation bands and compaction bands) or hybrids of different mechanisms (e.g. shear enhanced compaction bands). Cataclastic deforma tion bands are frequently observed around larger normal faults in soft sediment and weakly lithified rocks, and display the incipient stage of faulting and strain hardening (Antonellini \& Aydin 1995; Fossen 2010; Ballas et al. 2012; Soliva et al. 2013). They 
are reported to have no or only a very little impact on reservoir properties due to their spatially limited geometry and the limited interconnectivity in three dimensions (e.g. Fossen \& Bale 2007), while their clustering may act as a permeability barrier that reduces fluid flow by up to four orders of magnitude (e.g. Saillet \& Wibberley 2013).

The geometry, evolution and different scaling relationships of deformation bands have been stud ied in many outcrops (e.g. Antonellini \& Aydin 1994; Fisher \& Knipe 2001; Ogilvie \& Glover 2001; Schultz \& Fossen 2002; Davatzes \& Aydin 2003; Eichhubl et al. 2004; Olsson et al. 2004; Parry et al. 2004; Eichhubl \& Flodin 2005; Sternlof 2006; Ahmadov et al. 2007; Rotevatn et al. 2007; Johansen \& Fossen 2008; Schultz et al. 2008; Guo et al. 2009; Kolyukhin et al. 2009; Fossen 2010; Fossen et al. 2011; Ballas et al. 2012; Chemenda et al. 2012; Exner et al. 2013; Nicol et al. 2013; Saillet \& Wibberley 2013; Schueller et al. 2013; Schultz et al. 2013; Soliva et al. 2013; Awdal et al. 2014; Torabi 2014). While deformation bands often strike parallel to extension faults, local stress per turbations around faults, fault splays and in relay ramps may result in multiple sets of deformation bands (e.g. Antonellini \& Aydin 1995; Johansen et al. 2005; Rotevatn et al. 2007).
In this study, we analyse the apparent permeabil ity anisotropy of moderately to very well sorted Rotliegend sandstone cores, and the influence of cataclastic deformation bands and bedding anisotro pies on fluid flow. From microstructural analyses, we derive a scaling relationship that considers the width of the cataclastic deformation bands and the grain size of the undisturbed host rock, which is cor related with the apparent permeability data. Data mining tools are used to better display variations of deformation bands in a reservoir. Finally, trans missibility calculations in relation to deformation band frequency and the assessment of deformation bands from core material are critically discussed.

\section{Geological setting}

The Rotliegend gas producing reservoir is situated in a part of the north south orientated fan shaped Graben setting in the North German Basin in the area between Bremen, Hamburg and the Elbe river (Kayser 2006). It is part of the Southern Perm ian Basin, and accumulated thick successions of Upper Rotliegend continental siliciclastics and evaporites. The Permian horst and graben struc ture (Fig. 1) was affected by Triassic Cretaceous

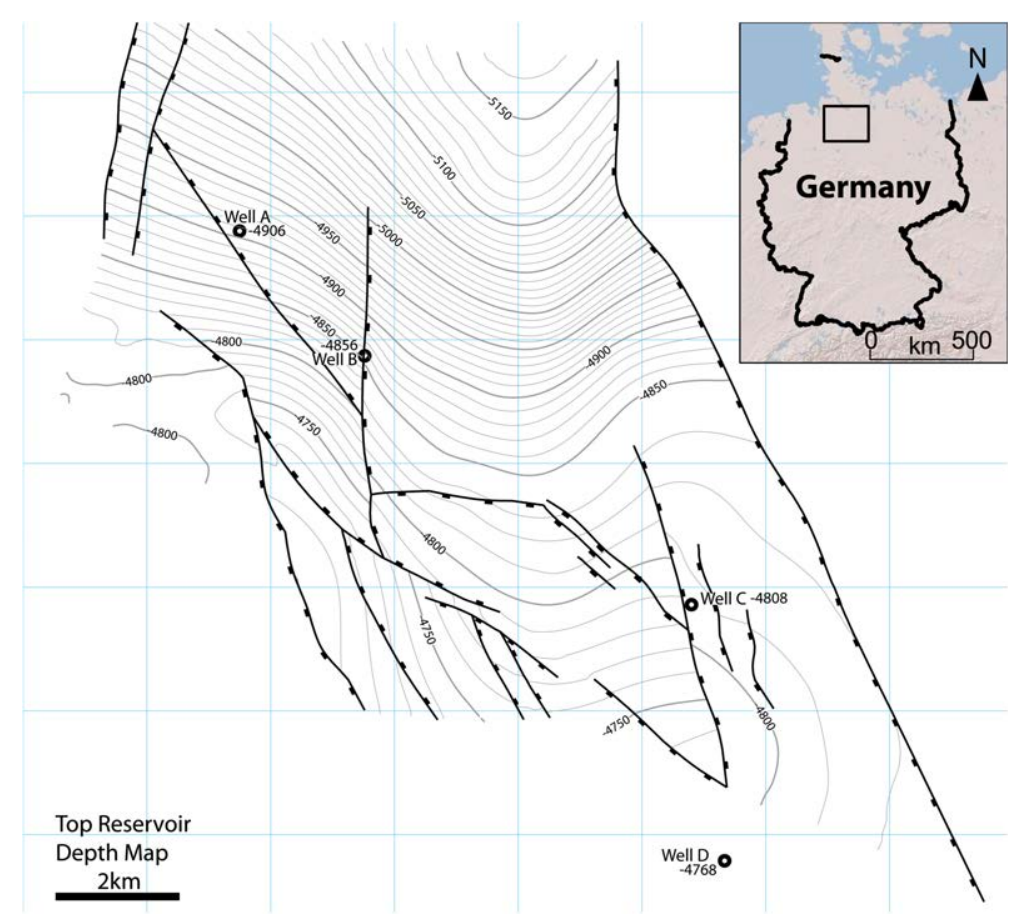

Fig. 1. Location of the study area in northern Germany (right), and the structure and depth map of the top of the reservoir unit including well locations (left). 
extension and the formation of Zechstein salt struc tures (Vackiner 2011). The geological evolution was followed by Upper Cretaceous north south orientated compression, concurrent inversion and further anticlockwise stress rotation to the recent stress field in the Late Eocene Miocene (Lohr et al. 2007; Kley et al. 2008; Legler \& Marchel 2008). The sediments have mainly been deposited in an arid semi arid desert environment and the red grey sandstones fall into the field of lithic subarkoses subarkoses (Legler \& Marchel 2008). The main reservoir target for exploration and production is the Upper Rotliegend Havel Subgroup (266 262 Ma: Menning 1995) (Fig. 2), which has a thick ness of $300400 \mathrm{~m}$ in the studied wells. It overlies Lower Rotliegend volcanics at the base. The present lithotypes, as characterized on resistivity image logs, are divided into dune, sandsheet and alluvial fan deposits.

\section{Materials and methods}

The database comprises resistivity image logs, gamma ray logs and lithological logs of four wells, including core material. The available samples were 14 plugs from core material for permeability

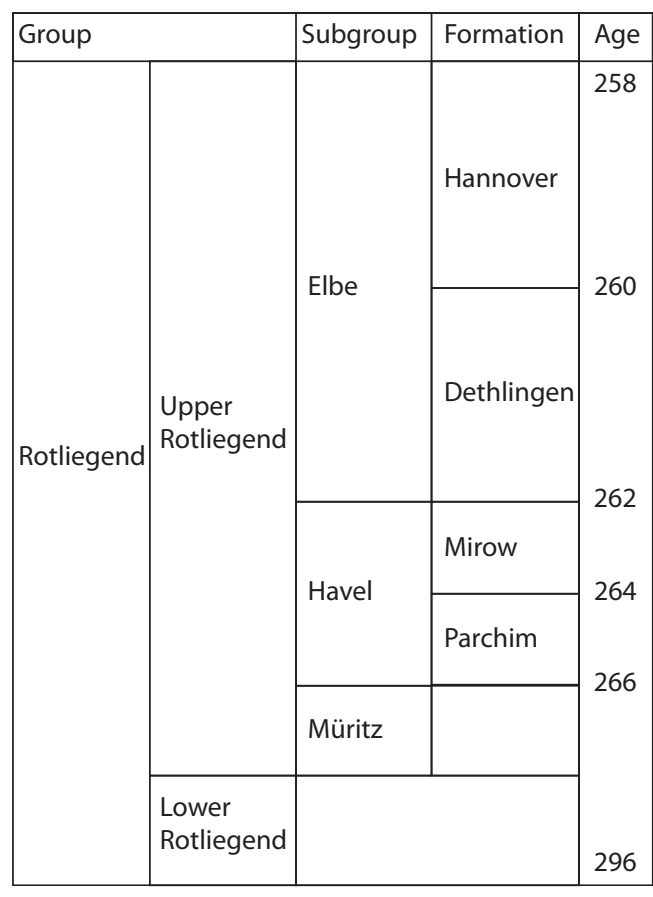

Fig. 2. Stratigraphic subdivision of the Rotliegend in northern Germany (after Schöner 2006; stratigraphic ages from Menning 1995). measurements and 32 petrographical thin sections of four wells. Overall, plugs were taken from dune and sandsheet deposits at a reservoir depth of between 4768 and $5251 \mathrm{~m}$.

Plugs, $30 \mathrm{~mm}$ in diameter and $40 \mathrm{~mm}$ in length, were used for permeability measurements, con ducted in a high pressure flow cell at well defined pressure $(P)$ and monitored temperature conditions $\left(P_{\text {conf }}=6.5\right.$ and $32 \mathrm{MPa}, P_{\text {fluid }}=0.12 \mathrm{MPa}$, $T=25 \pm 3^{\circ} \mathrm{C}$ ). In order to prevent bypass of the permeating fluid, the samples were tightly sealed with a rubber sleeve before being placed in the water filled autoclave. Argon was used as permeant for the pressure pulse decay measurements. Fluid pressures on both sides of the sample were continu ously monitored, with the upstream pressure $\left(P_{1}\right)$ held constantly at $1.8 \mathrm{MPa}$. The downstream pres sure $\left(P_{2}\right)$ within a previously calibrated reservoir $\left(V_{2}=1.02 \times 10^{5} \mathrm{~m}^{3}\right)$ was allowed to equilibrate, starting from atmospheric conditions (Freund \& Nover 1995; Fowler et al. 2005). Apparent gas per meability coefficients were derived numerically by least square fitting to the measured pressure decay data. Calculation was based on Darcy's law for com pressible media (e.g. Hildenbrand et al. 2002):

$$
\frac{\mathrm{d} n}{\mathrm{~d} t} \quad \frac{V_{2} \mathrm{~d} P_{2}}{\mathrm{~d} t} \quad \frac{k_{\text {gas }} A\left(P_{2}^{2}\right.}{\eta 2 x} .
$$

Here, the amount of mass ( $\mathrm{d} n[\mathrm{~mol}])$ moving through the sample is calculated from the pressure change with time $\left(\mathrm{d} P_{2} / \mathrm{d} t\left[\mathrm{~Pa} \mathrm{~s}^{1}\right]\right)$ in reservoir $V_{2} . A\left[\mathrm{~m}^{2}\right]$ is the cross sectional area of the plug, $\eta$ is the dynamic viscosity [Pa s], $x$ the sample length $[\mathrm{m}]$ and $k_{\text {gas }}\left[\mathrm{m}^{2}\right]$ is the apparent gas perme ability. A reliable Klinkenberg correction could only be performed for seven samples. In order to obtain values for all samples, we additionally calcu lated Klinkenberg corrected permeability values $\left(k_{\infty}\right)$ according to a trend given by Jones \& Owens (1980), which was based on more than 100 tight sandstones samples. The trend indicates larger slip factors for rocks with lower permeability. Both methods yielded largely consistent $k_{\infty}$ values. In general, Klinkenberg corrected permeability coeffi cients are $12 \%( \pm 8 \%)$ lower than measured appar ent gas permeabilities.

However, in the following, we will concentrate on the interpretation of the apparent gas permeabil ities. This is to avoid the usage of (probably inac curate) extrapolation. As all measurements were conducted under the same experimental conditions, apparent permeability values of the present sample set can be used for heterogeneity analysis (compar ison between samples).

All permeability experiments were performed parallel to bedding. To investigate the influence of 
deformation bands on bedding parallel apparent permeability, different pairs of sample plugs were prepared (undisturbed host rock v. samples with cataclastic deformation bands). The corresponding sample pairs were taken directly adjacent to one another from core material.

Two samples were measured twice at a $6.5 \mathrm{MPa}$ confining pressure before and after peak pressures of $30 \mathrm{MPa}$. The permeability was determined at the given pressure steps.

In addition, data on Klinkenberg corrected per meability was provided for low confining pressures $(1.8 \mathrm{MPa})$ using air as the permeant. Plugs parallel to, as well as subnormal to, bedding allow access to the impact of bedding horizons on flow. To reduce the influence of possible microfractures that formed as a response to external stress release after coring (Holt 1994), permeabilities of plugs were measured stepwise at increasing confining pressures up to $32 \mathrm{MPa}$.

Based on this dataset, transmissibility multipli ers were calculated according to Manzocchi et al. (1999) for use in reservoir models:

$$
T M \quad\left[1+\frac{t_{\text {def }}}{L}\left(\frac{k_{\text {host }} k_{\text {def }}}{k_{\text {def }}}\right)\right]^{-1}
$$

where $T M$ is the transmissibility multiplier, $t_{\mathrm{def}}$ is the cumulative thickness of deformation bands in the calculated interval [m], $L$ is the length of the cal culated interval $[\mathrm{m}], k_{\text {host }}$ is the apparent host rock permeability $\left[\mathrm{m}^{2}\right]$ and $k_{\mathrm{def}}$ is the the apparent defor mation band permeability $\left[\mathrm{m}^{2}\right]$. For all calculations and assessments of deformation band occurrence around faults, a damage zone width of $20 \mathrm{~m}$ has been assumed (Guo et al. 2009). This width was also adapted to assess transmissibility multipliers of deformation bands in a damage zone.

Petrographical methods include standard trans mitted light microscopy, as well as cathodolumines cence (CL) microscopy performed with a HC3 LM, operated at an acceleration voltage of $13.5 \mathrm{kV}$ and a beam current density of $0.6 \quad 0.8 \mathrm{~mA} \mathrm{~mm}{ }^{2}$. Of the 32 petrographical thin sections, five were prepared without a cover slip for CL microscopy, which is the main tool to outline quartz cemented cataclastic quartz grains. Optical porosity was measured from thin sections stained with a low viscosity fluores cent dye. The representative elementary area (REA) was established by incrementally increasing the evaluated area on a photomosaic from $10 \times 10$ pixels up to the maximum area of the photomosaic $(\max .4000 \times 4000$ pixels on a $12000 \times 4000$ pixel photomosaic within one layer). It was deter mined that the REA had been reached when the measured optical porosity stopped changing. For the correlation of grain size and deformation band width, the average grain size was determined by averaging grain sizes measured along a grid in the host rock on either side of the deformation band. These data were taken adjacent to the site where deformation band width was measured. Ori entations of deformation bands were plotted on lower hemisphere Schmidt nets.

The analysis and data mining of revised Well CAD data (resistivity image log, gamma ray log and lithological $\log$ ) was performed with the graphi cal user interface 'Rattle' (Williams 2011), which is based on ' $\mathrm{R}$ ', an environment and programming lan guage for statistical computing. The 'latticist' plug in allows the study of changes in orientation with increasing depth on marginal plots, which show a distribution for defined intervals (margins). The depth resolution of orientation data (dip direction, dip), derived from resistivity image logs embedded in WellCAD, can be adjusted by changing the num ber of created margins for the target variable depth For this study, the number of margins was set to 4 to allow a significant number of deformation bands per interval $(\geq 40)$.

\section{Results}

\section{Petrography}

Most samples are similar in mineralogical compo sition and consist mostly of quartz (40 55\%) with alkali feldspar and plagioclase (6 $18 \%$ combined), lithoclasts (12 23\%), and iron oxide grains. Authi genic cements include quartz ( $015 \%)$, calcite $(0$ $6 \%)$ and feldspar $(05 \%)$. Accessory phases are always hematite and illite coatings and pore lining chlorite.

The studied cataclastic deformation bands from core material all show a simple shear displace ment between 0.4 and $15 \mathrm{~mm}$. All samples contain discrete variations in grain size, be it in the form of foresets of grainfall or grainflow laminae in dune sandstones or deflation layers in sheetsand deposits.

The undisturbed host rock for dune sandstones is marked by a characteristic pinstripe lamination (Fig. 3a, c e), which is due to grain size changes during deposition. Sand sheets (Fig. 3b) are charac terized by planar bedding and occasional defla tion lags, with an overall maximum of clay content of $1 \%$.

Heterogeneities in the mineral distribution of different lithotypes or within rocks of the same lithotype were not observed. Quartz overgrowth cementation is only observed in rocks with an incomplete coat coverage. Of the discussed flow barriers, only dissolution seams result in a sig nificant heterogeneity of the mineral distribution 
by enriching clay minerals within the dissolution seam.

Petrographical analyses show that almost all studied deformation bands contain cataclasis of different degrees and cementation (Fig. 3a d). Cat aclasis in the studied samples is followed by sub sequent quartz cementation. Thus, cataclasis is often invisible in transmitted light microscopy but shows up well in hot CL microscopy, which displays intragranular fractures of detrital quartz cemented by quartz of different luminescence (Fig. 4c).

Thicknesses of deformation bands vary and do not necessarily depend on the amount of displace ment along the deformation band. Generally, thin ner bands $(0.21 \mathrm{~mm}$ thickness $)$ occur in tightly cemented, densely packed and generally finer grained host rocks. Thicker bands, up to $10 \mathrm{~mm}$ wide, occur in less cemented layers and rather coarse grained intervals (Fig. 3b, c). A correlation between the average grain size in the host rock and the deformation band width exists for the stud ied cataclastic deformation bands, with a coefficient of determination of $R^{2}=0.74$ (Fig. 5a). All studied samples of the host rock show a wide spread in grain diameters from $<0.1$ to $0.9 \mathrm{~mm}$, occasionally including grains as large as $1.1 \mathrm{~mm}$. The skewness of the distribution, as well as the Trask sorting, only poorly correlate with the width of cataclastic deformation bands (Fig. 5b). The median grain size resulted in the best correlation with deformation band width, only differing slightly from the average grain size in most cases (Fig. 5b).

Incipient deformation bands show grain grain contacts with minor chemical compaction along quartz grain boundaries and quartz cements in adja cent pore space. They are orientated oblique to bed ding, forming a load bearing framework. Incipient deformation bands are occasionally aligned in linear arrays at a high angle to bedding (Fig. 3d). These arrays of grain grain contacts and linear quartz overgrowth cements are also observed in the tran sition zone between the deformation band core and the undisturbed host rock (Fig. 4a). In areas of two cataclastic bands merging into one band, no increase in cataclasis is observed, only an increase in chemical compaction (Fig. 3e \& f). Localized bedding parallel cementation occurs predominantly in fine grained layers (e.g. Fig. 3e)

Next to the 29 cataclastic deformation bands, only a few other types of deformation bands or subvertical flow barriers were observed, which include two cementation bands (no shear com ponent, continuous cementation with calcite at a medium to high angle to bedding: Fig. 2a), one dis aggregation band (characterized by simple shear, disaggregation and dissolution) and one vein (char acterized by simple shear, dilation and calcite cementation).
The visible porosity inside the band was opti cally assessed by fluorescent staining and compared to the host rock (Fig. 6). Porosity inside a defor mation band was analysed in one sample using dig ital image analysis and was found to be $2.1 \pm 0.2 \%$. Host rock porosity ranges from $10.8 \pm 0.7 \%$ in the fine grained layers to $15.5 \pm 0.5 \%$ in coarser grained layers of that same sample. In another sample, the porosity inside the deformation band was much lower, at $0.18 \pm 0.05 \%$. Host rock val ues in this sample range from $1.2 \pm 0.08$ to $2.9 \pm 0.3 \%$ for two coarse grained bedding inter vals of the host rock, and from 0.4 to $1.3 \%$ for one fine grained layer.

Two dissolution seams in the studied samples are enriched in illitic clay minerals, which are present as grain coating clays in most parts of the undisturbed samples. They developed parallel to bedding planes and foresets in dune layers, which suggests forma tion during chemical compaction (also frequently termed 'pressure dissolution'). However, chemical compaction post dates at least one set of cataclastic deformation bands, as derived from cross cutting relationships (Fig. 3b). In most samples, dissolution seams are concentrated in the fine grained intervals. In the case of non densely packed finer grained lay ers, the area surrounding the dissolution seam is intensely cemented.

\section{Data mining}

Resistivity image logs were used to analyse the ori entation and depth of the flow barriers. The conduc tive medium in the horizons is mainly the porewater. Flow barriers on resistivity image logs appear as more resistive features due to the loss or lack of porosity, and are, in the case of cataclastic deforma tion bands, orientated oblique to bedding and show a slight offset of the bedding planes. Bedding parallel compaction is most likely to be masked by the bimo dal sorting of the sediment. The lithotype associa tion was applied consistently throughout the four different wells.

The dependency of deformation band density on lithotypes. The pre picked lithologies in litholog ical $\log$ files were analysed to determine the num ber of deformation bands per metre $(\mathrm{DB} / \mathrm{m})$. No consistent trends concerning the different lithologi cal units (dunes, sand sheets, alluvial fans) could be established (Fig. 7). The number of deformation bands per metre in well $\mathrm{B}$ range from 0 to $5.7 \mathrm{DB} / \mathrm{m}$. The $50 \%$ data accumulation between the first $(25 \%$, Q1) and the third (75\%, Q3) quartile shows the wid est spread for the dune facies lithotype. All litho types exhibit a median of $0 \mathrm{DB} / \mathrm{m}$ for well $\mathrm{B}$. In well $\mathrm{D}$, the deformation band frequency ranges from 0 to $7.75 \mathrm{DB} / \mathrm{m}$. The median for all lithotypes 

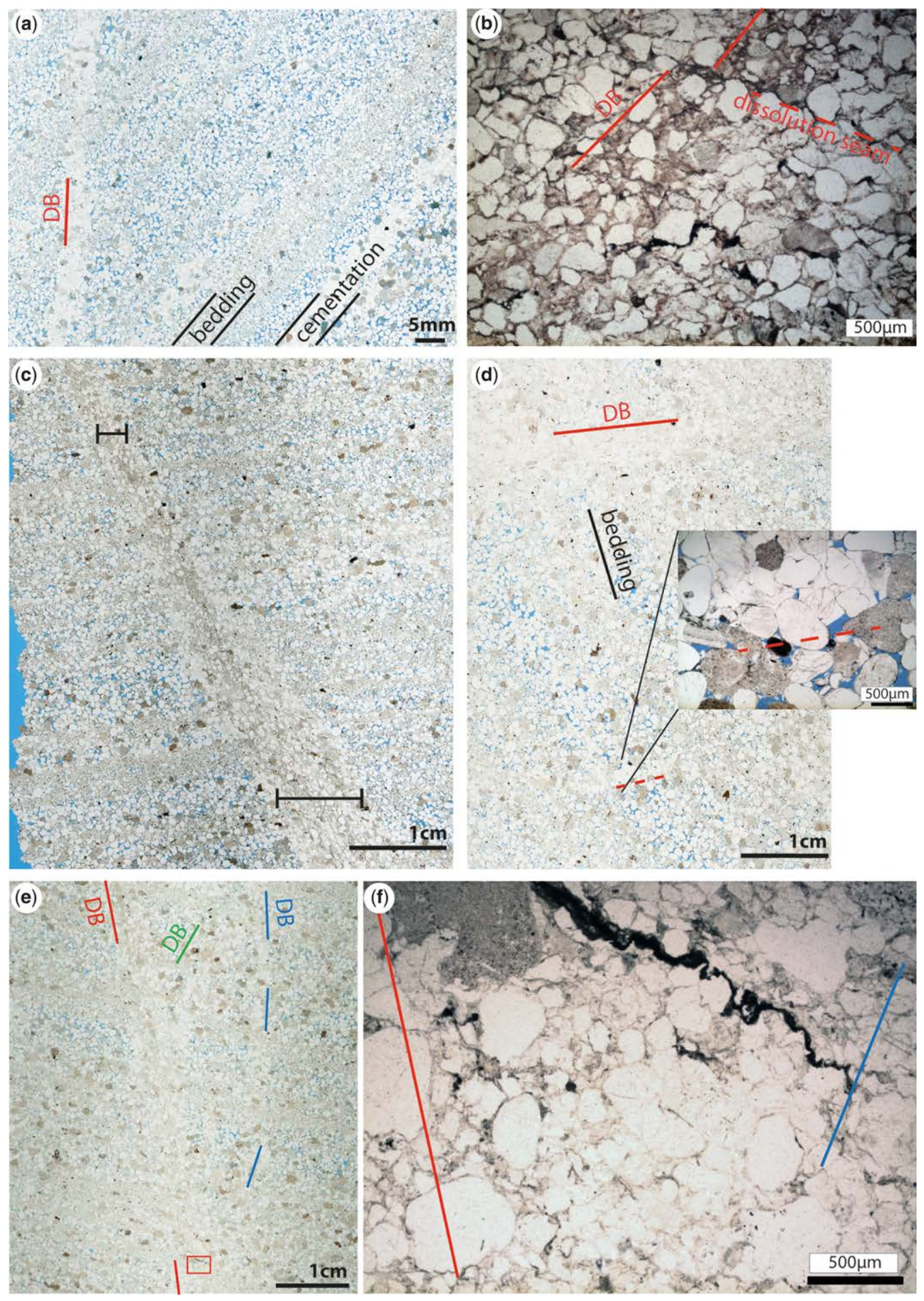

Fig. 3. (a) Cataclastic deformation band at a high angle to bedding marks a zone of low porosity. The host rock shows differences in grain size in the bedding and bedding parallel cementation. (b) Compaction related dissolution seam parallel to bedding, which sets off a deformation band, indicates early formation of a deformation band prior 
is between 0 and $1 \mathrm{DB} / \mathrm{m}$, but does not exhibit a clear accumulation within one lithotype.

The dependency of deformation band density on faults. Fault dependency was studied qualitatively from resistivity image logs and by calculating cor relation coefficients of fault displacements v. num ber of deformation bands in the vicinity around faults. The lithotype dependency has been neglected due to the minor mineralogical differences of often closely spaced lithotypes. The maximum of ob served displacements on faults was $30 \mathrm{~cm}$. Well log data show no clear accumulation of deformation bands around small scale normal faults. A correla tion could not be established either to the occurrence or to the displacement of small scale faults inter preted from resistivity image logs (Fig. 8). In comparison to the other wells, well D (crosses in Fig. 8) exhibits a larger number of deformation bands within the studied intervals, even at small observed displacements.

Marginal plots: orientation data. The depth dependent orientation trends were visualized by marginal plots, which split the dataset into four depth intervals (margins). Each depth interval in one well contains the same number of deformation bands. The intervals therefore can cover different lengths of the well section. The plots for the four studied wells are presented in Figures 9 and 10 The first row in each plot visualizes the distribution of deformation bands along the well log interval. The second row shows the dip direction and number of deformation bands in each depth interval. The third row shows the dip and number of deformation bands in each depth interval with the according dip angle.

In wells $\mathrm{B}$ and $\mathrm{D}$, the deformation bands are accumulated in the second and third depth interval (blue and green line) (Fig. 9a, b). These depth inter vals cover parts of the Rotliegend stratigraphy of the Havel subgroup in both wells. The dip directions of resistive features in well B show a somewhat con sistent bimodal distribution with a minor maximum at around $270^{\circ}$ for all depth intervals and a second major maximum at about $90^{\circ}$. This reflects the con sistent conjugate alignment of deformation bands along the well. The lowermost interval in well $\mathrm{B}$ (red line) comprises resistive (veins) and conduc tive features (fractures) picked in the underlying
Rotliegend volcanics interval of the log section, which explains the deviation from the consistent trend. The very minor maximum of dip directions towards about $180^{\circ}$ in the third depth interval (green line) points to the accumulation of a few resistive features deviating from the consistent trend. The unimodal distribution of dip values ranges around $60^{\circ}$ and reflects a conjugate exten sional system.

Well D also shows a bimodal distribution of deformation band dip directions (Fig. 9b). However, their strike does not match with those of well B, indicating a different local stress regime around well $\mathrm{D}$ during deformation band formation. Maxima at approximately $40^{\circ}$ and $210^{\circ}$ dip direction sug gest a conjugate arrangement in the uppermost (pur ple line) depth interval. Dip directions also suggest a clockwise rotation of about $20^{\circ}$ with depth, as indicated by aligning the peaks of the following two deeper depth intervals. At greater depth (blue to red line intervals) deformation bands dipping towards $300^{\circ}$ become increasingly more promi nent, which indicates a similar clockwise rotation in strike. The dip values show an accumulation of shallower dips in the interval between 5079 and $5150 \mathrm{~m}$ (green line). In contrast to well B, dips are dominantly bimodal, with one maximum at a more shallow dip of $50^{\circ}$ and a second maximum at a steeper dip. There appears to be an increasingly steeper dip with increasing depth from approxi mately $70^{\circ}$ to $80^{\circ}$.

In well $\mathrm{A}$, the number of deformation bands increases with depth (Fig. 10a). Dip directions of deformation bands show a bimodal distribution with maxima at about $90^{\circ}$ and $270^{\circ}$, indicating a conjugate set of deformation bands. Similar to well $\mathrm{D}$, steepest dips of around $80^{\circ}$ are observed at the deepest depth intervals. An anticlockwise rota tion in dip direction is indicated by arranging the peaks of the top three intervals (purple, blue and green line) around $90^{\circ}$. A second more prominent azimuth of about $200^{\circ}$ is present in the lowermost depth interval. The lowermost interval (5199 $5424 \mathrm{~m}$ ) for this well only comprises fractures of the Rotliegend volcanics, causing the deviation from the consistent trend.

In well $\mathrm{C}$, the deformation bands are accumu lated in the second and third depth interval (blue and green line) (Fig. 10b). The distribution of dip directions has four somewhat consistent maxima

Fig. 3. (Continued) to chemical compaction. (c) Cataclastic deformation band thickness (black lines) increases with an increase in average host rock porosity and grain size. (d) Cemented area parallel to the deformation band (DB, red line) forming a load bearing structure in a relatively porous host rock. (e) Thin section with three linking cataclastic deformation bands (DB), the red box covers the area of f). (f) In the concourse area of two linking cataclastic deformation bands, an increase in chemical compaction but no increase in cataclasis is observed. Porosity is coloured in blue. 

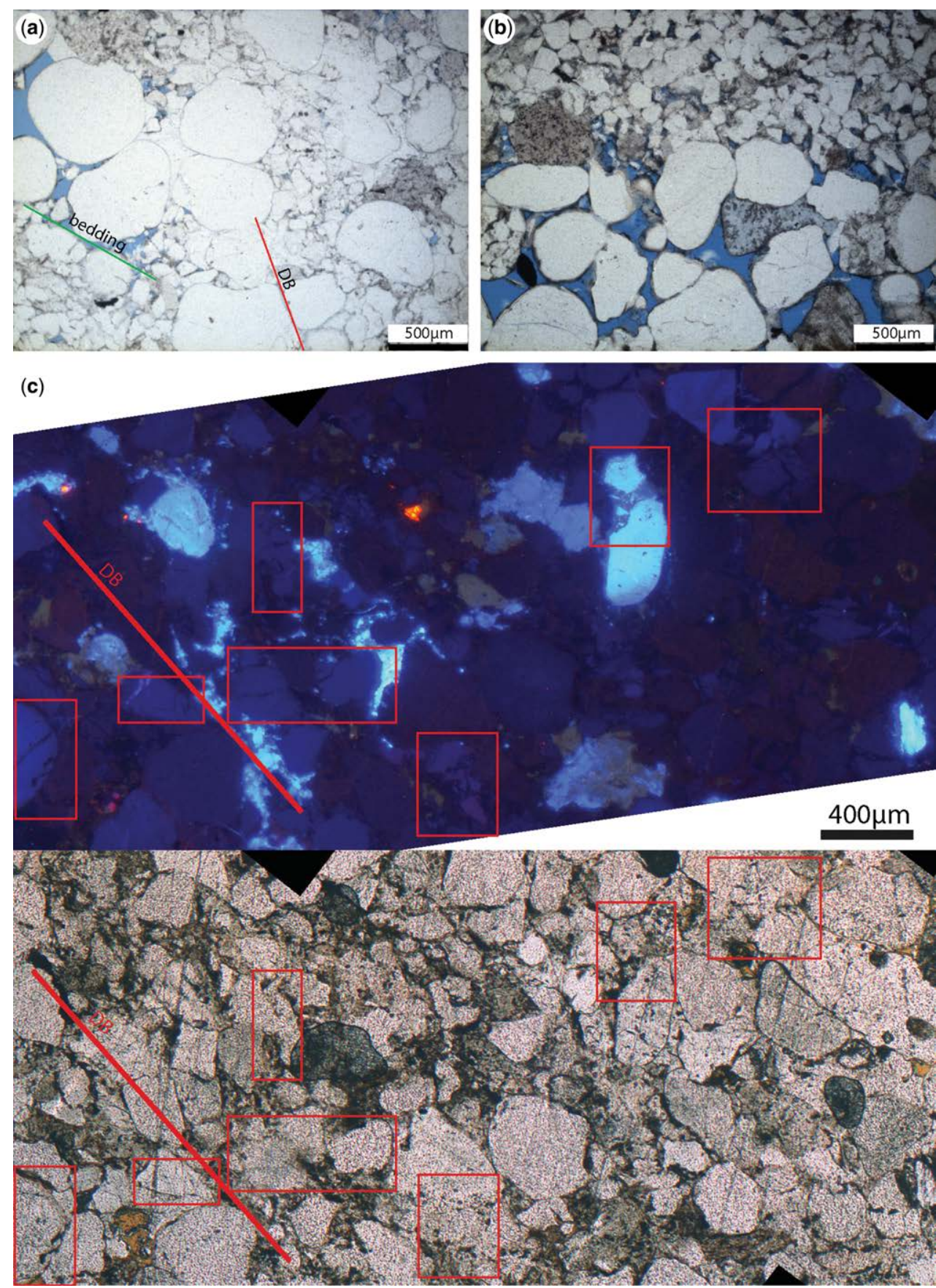

Fig. 4. (a) Cemented margin of a cataclastic deformation band interpreted to be the remains of an incipient cataclastic band. The pore space (blue colour) away from the deformation band is uncemented (upper left an right hand corner). (b) Mainly chloritic grain coatings (light green colour) on coarse grained quartz grains preserve porosity in deeply buried sandstone samples. (c) Comparison of a cataclastic band in cathodoluminescence (CL, top image: bright blue colours are illite and feldspar; dark blue colours are quartz; orange colours are carbonates) and in transmitted light (bottom, plane polarized light (PPL)). Occasionally, one can infer the cataclasis in ppl images, but often the broken and healed grains of different quartz generations are only visible in CL microscopy. 

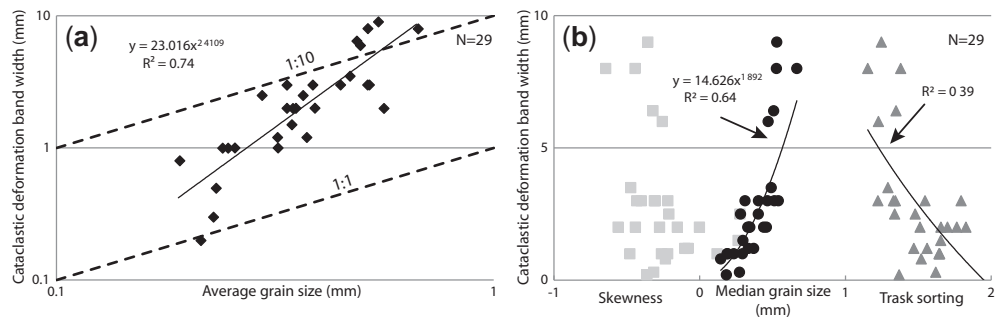

Fig. 5. (a) Correlation of average grain size in the undisturbed host rock v. deformation band width. The trend indicates that a larger grain size of the host rock results in wider deformation bands. Dashed lines indicate a 1:1 and 1:10 scaling relationship. (b) Correlation of skewness of the grain size distribution, median grain size (in $\mathrm{mm}$ ) and sorting v. the width of cataclastic deformation bands. The median grain size shows the best correlation.

at approximately $290^{\circ}$. The second maximum is located between $70^{\circ}$ and $120^{\circ}$. The $70^{\circ}$ dip direction corresponds well with the dip direction extracted from seismic line interpretation and is present in the lowermost interval, as well as subordinately in the shallowest interval (red and purple lines). The dominant dip values steepen with depth (blue to red line intervals) from about $55^{\circ}$ to $70^{\circ}$. However, steepest dips of $80^{\circ}$ are also dominant in the shal lowest depth interval (4888 $5073 \mathrm{~m}$, purple line).

The strike of deformation bands present in resis tivity image logs locally differs from seismi cally observable fault strike (Fig. 11). In the case of well A, the resistivity image log, covering all of the Havel subgroup, shows no small scale resistive features indicating faults of the given strike $\left(145^{\circ}\right)$, as is noted in the structural map (Fig. 1). The fault that is noted on the structural map was derived only from production data (Fig. 11, ellipse around well A). This fault strike derived from production data can only be seen in small scale faults, fractures and resistive features (veins) of the underlying Rot liegend volcanics. However, it is not reflected by resistivity anisotropies (deformation bands, faults, veins) in the reservoir unit. In the case of well $\mathrm{D}$, the resistivity $\log$ data (strike of deformation bands, faults, veins) suggests that only one orienta tion of faults interpreted from seismic sections matches one of the two main orientations of the small scale resistive features. In addition, the sec ond orientation is accumulated in a certain depth interval (green line Fig. 9b).

\section{Permeability}

The apparent permeability at increasing confining pressures decreases non linearly. Measured data were fitted by exponential regressions, which are given in Figure 12a d. Generally, the decrease in apparent permeability from 6.5 to $32 \mathrm{MPa}$ confining pressure was less than one order of magnitude (Fig. 12a c).

The stress dependency of measured apparent permeability can well be described by an expo nential function (cf. David et al. 1994). The stress dependency factor, $\gamma$, of our samples ranges between 0.005 and $0.079 \mathrm{MPa}{ }^{1}$.

The apparent permeability of the host rock samples (Fig. 12, squares) are larger than those of adjacent samples containing a deformation band (Fig. 12, diamonds). At higher confining pressures, this difference remains almost constant for each

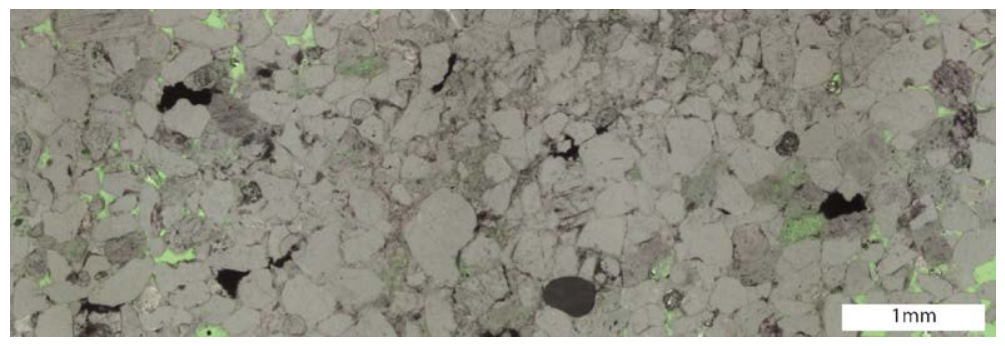

Fig. 6. Thin section stained with fluorescent dye to highlight porosity (green color) in comminuted cataclastic deformation band. Dyed porosity inside the deformation band (central part of image) can clearly be differentiated from the porosity of the host rock (left and right side of image). Digital image interpretation and thresholding of the green fluorescent dye resulted in $2.1 \pm 0.2 \%$ visible porosity in the deformation band. 
(a)

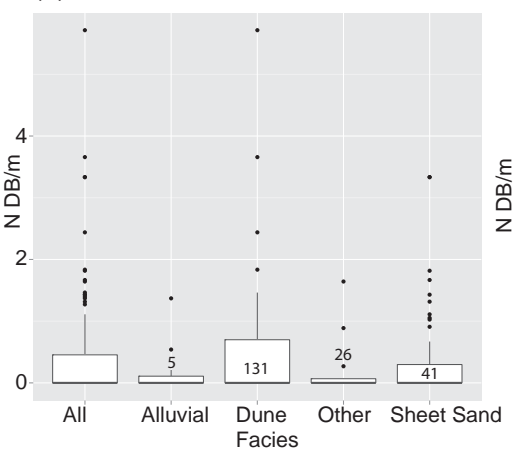

(b)

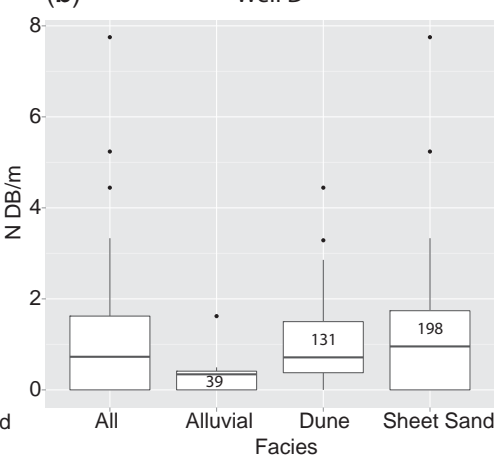

Fig. 7. Box whisker plots for two wells B (a) and D (b) present the number of deformation bands per metre (DB/m) v. lithotype. Numbers next to the boxes indicate the number of deformation bands analysed in this lithotype. No clear accumulation of deformation bands in one lithotype as characterized from well logs and resistivity image logs can be determined. The dependency of deformation bands to fault throw, grain size and distance to faults had to be neglected owing to the restricted $1 \mathrm{D}$ database.

sample set with less than one to more than one order of magnitude (Fig. 12a, b). Only sample set 4 shows a continuous increase in apparent perme ability reduction from one to nearly two orders of magnitude during increasing confining pressure (Fig. 12c).

The apparent permeability reduction of sample 7 is smaller than in other more porous samples at $30 \mathrm{MPa}$ confining pressure (Fig. 12a, squares), which is due to specific microstructual differences. Here, the deformation band is located in a fine grained, well cemented and densely packed host rock. The thin nature of the deformation band in this fine grained host rock only reduces the appar ent permeability by 0.7 orders of magnitude with respect to the undisturbed sample at $30 \mathrm{MPa}$ con fining pressure (Fig. 12a). Coarser grained host rocks favour the development of wider deforma tion bands, which result in a larger apparent per meability reduction (Fig. 12b, c).

The Klinkenberg corrected permeability across bedding parallel cementation and dissolution seams could only be inferred from low confining pres sure data using air as the permeant (grey crosses and box in Fig. 12d). These data indicate that the permeability measured perpendicular to bedding

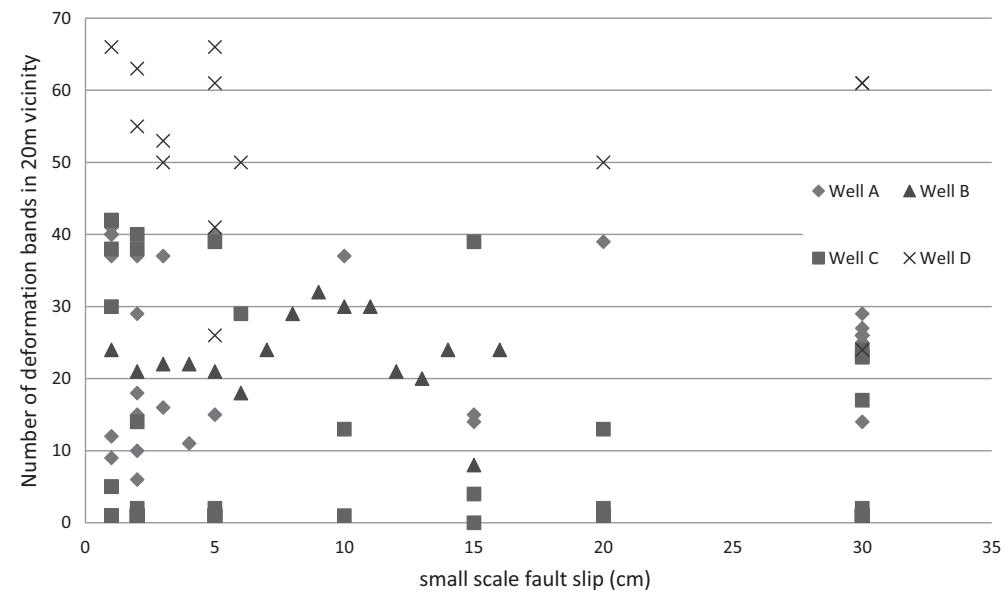

Fig. 8. Plot of small scale fault slip taken from image $\operatorname{logs} \mathrm{v}$. the number of deformation bands in a $20 \mathrm{~m}$ vicinity around the fault. No clear trend concerning the dependency of deformation band density in a certain interval v. fault slip can be established from the 1D image logs. A possible lithotype dependency has been neglected. 

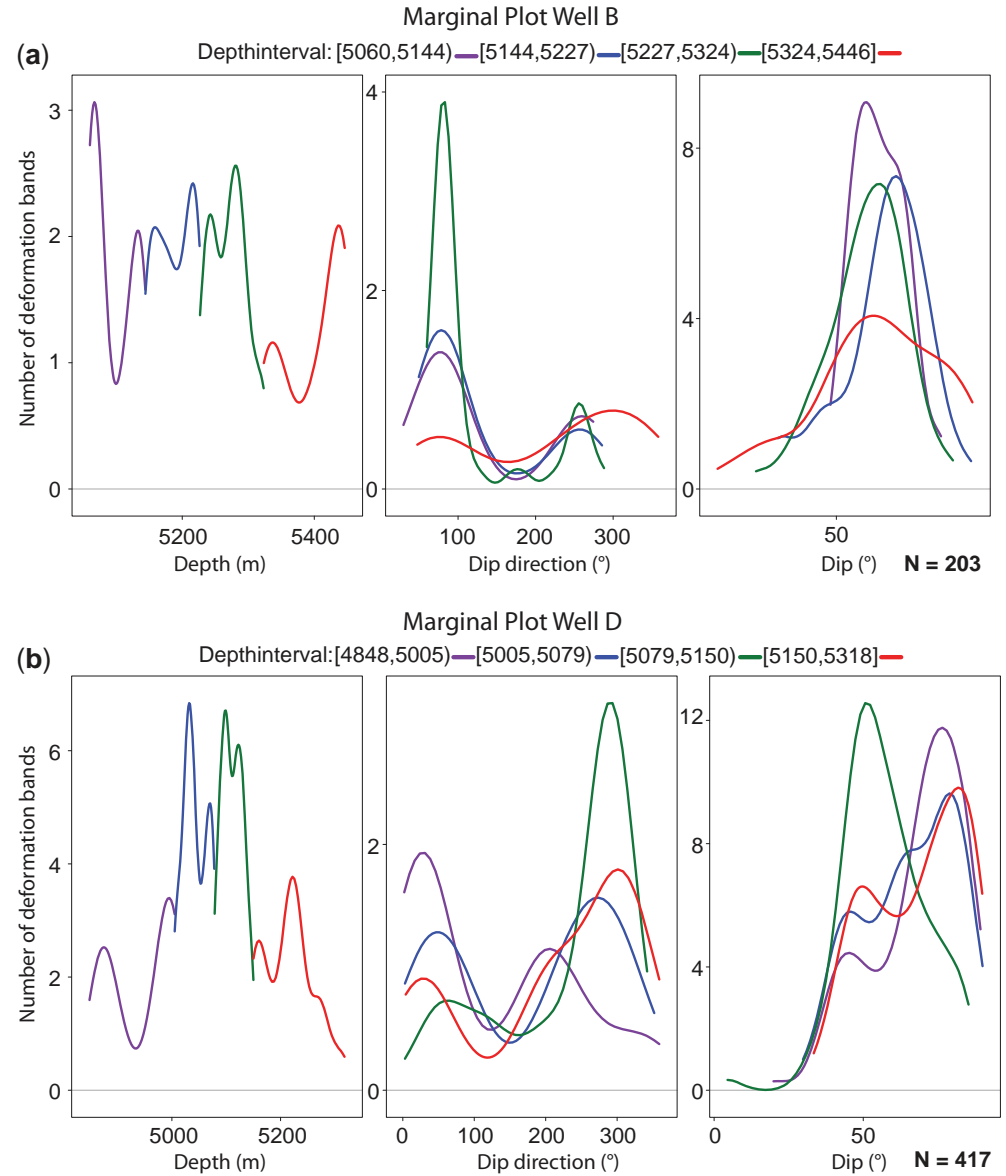

Fig. 9. Marginal plots for wells B (a) and D (b) for different depth intervals. The total number of deformation bands is given as $\mathrm{N}$. The four depth intervals (margins) from top to bottom are a purple, blue, green and a red line. The corresponding depth intervals are given at the top of each plot. (First row) Distribution of deformation bands along the log interval. (Second row) Azimuth of deformation bands in each depth interval; note the accumulation in well D between 5079 and $5150 \mathrm{~m}$ (green interval). (Third row) Dip of the deformation bands in each interval; note the inhomogeneous distribution in well $\mathrm{D}$ in comparison to well $\mathrm{B}$.

(grey crosses, Fig. 12d) is up to four orders of mag nitude lower than the corresponding permeability parallel to bedding (grey box in Fig. 12d)

Two experiments on host rock samples (3B and 7B) after a subsequent stress reduction from $30 \mathrm{MPa}$ down to $6.5 \mathrm{MPa}$ resulted in a lower apparent per meability of 10 and $15 \%$, respectively.

During the measurements, several samples, which are not presented, fractured at low, as well as at high, confining pressures. One sample com pletely disintegrated to sand, others partly dis aggregated.

Transmissibility multipliers were calculated for peak confining pressures of $30 \mathrm{MPa}$ using the given apparent permeability data calculated for the width of the deformation band. These transmissibility mul tipliers (equation 2) were calculated for deformation band frequencies that were determined from the actual resistivity image logs (sample series A). A worst case scenario (sample series B) was assumed for $100 \mathrm{DB} / \mathrm{m}$ and a frequency taken from a pub lished field example (sample series C) from Johan sen \& Fossen (2008) (Table 1). Thresholds for the sealing efficiency are based on transmissibility multiplier calculations by Shipton et al. (2005), who suggested that deformation bands are seal ing at $T M<0.0005$ on geological timescales and $T M<0.001$ on production timescales. Transmissi bility multipliers show that the sampled deformation bands do not completely seal off fluid flow in the 

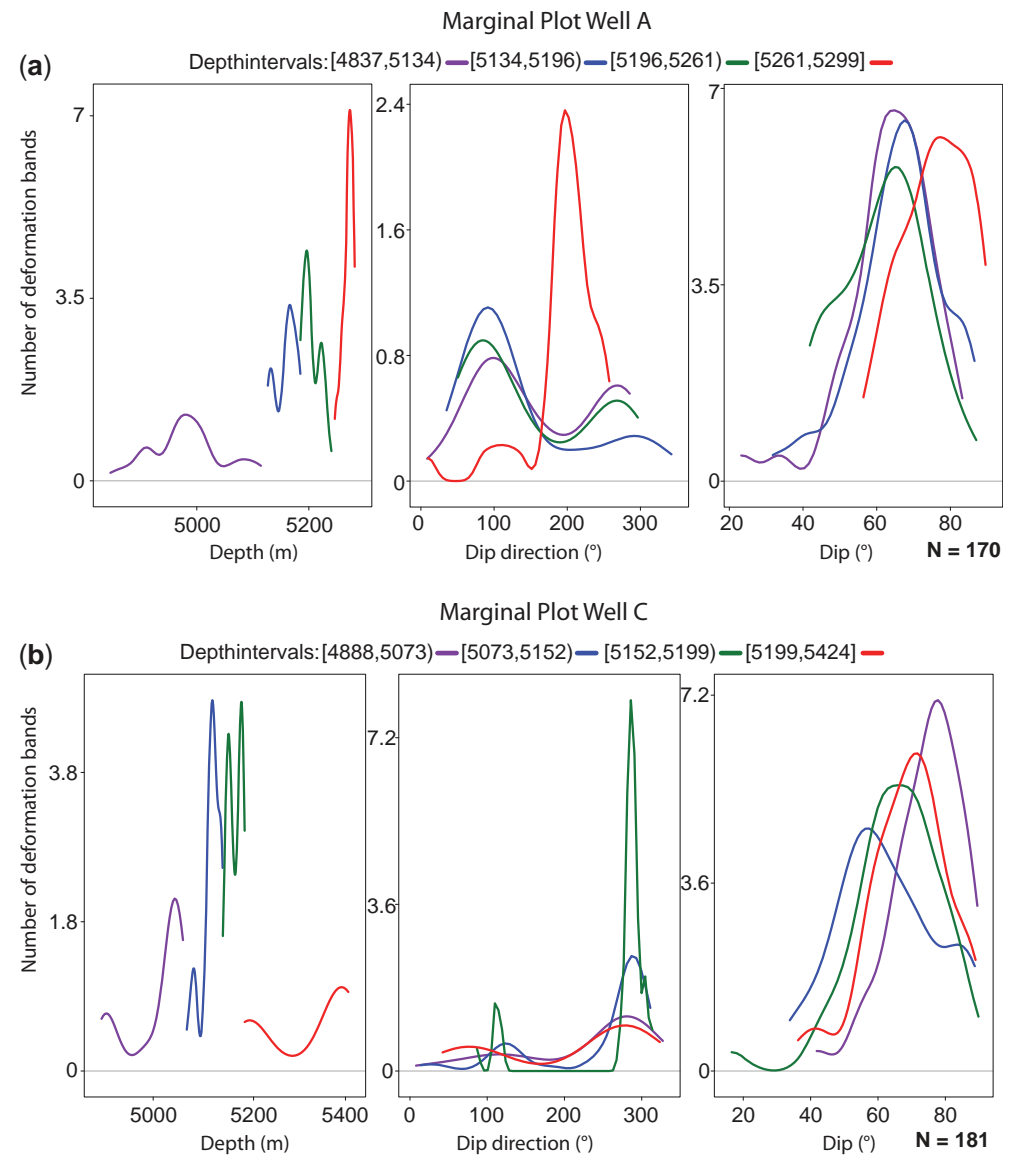

Fig. 10. Marginal plots for wells A (a) and C (b) for four different depth intervals. (First row) Distribution of deformation bands along the log interval. (Second row) Azimuth of deformation bands in each interval. (Third row) Dip of deformation bands in each interval. Well C: lowermost interval (5199 $5424 \mathrm{~m}$ ) represents fractures and veins in the volcanic units.

reservoir under the given assumptions, not even at reservoir confining pressure conditions (Table 1). Contrary to this, production data have shown that flow barriers do stop flow parallel to bedding.

\section{Discussion}

\section{Petrography}

The optical evaluation of deformation bands from thin sections, coupled with apparent permea bility measurements, better constrains the impact of deformation bands on fluid flow in the reser voir. The absence of grain coatings and the high reactivity of fractured quartz grains enhance the cementation of cataclastic grains (Fisher et al. 2000; Fossen et al. 2007). In the studied samples, such masking of cataclasis in deformation bands is visualized by CL microscopy, which is recom mended to verify the presence of brittle deformation in grains.

A correlation of deformation band thickness and grain size was described by Wennberg et al. (2013, fig. 12 and references therein) for carbonates and sandstones. Our results for sandstones are in accordance with their findings, with a good corre lation of cataclastic deformation band thickness v. the host rock grain size adjacent to the band (Fig. 5). Such correlation also links to our petro physical measurements, which show an increase in the apparent permeability reduction with increas ing deformation band width. It allows a first appar ent permeability prediction and thus points to the role of deformation band width on fluid flow in a res ervoir (Fig. 13). A greater number of data should be generated to further support the overall trend. 


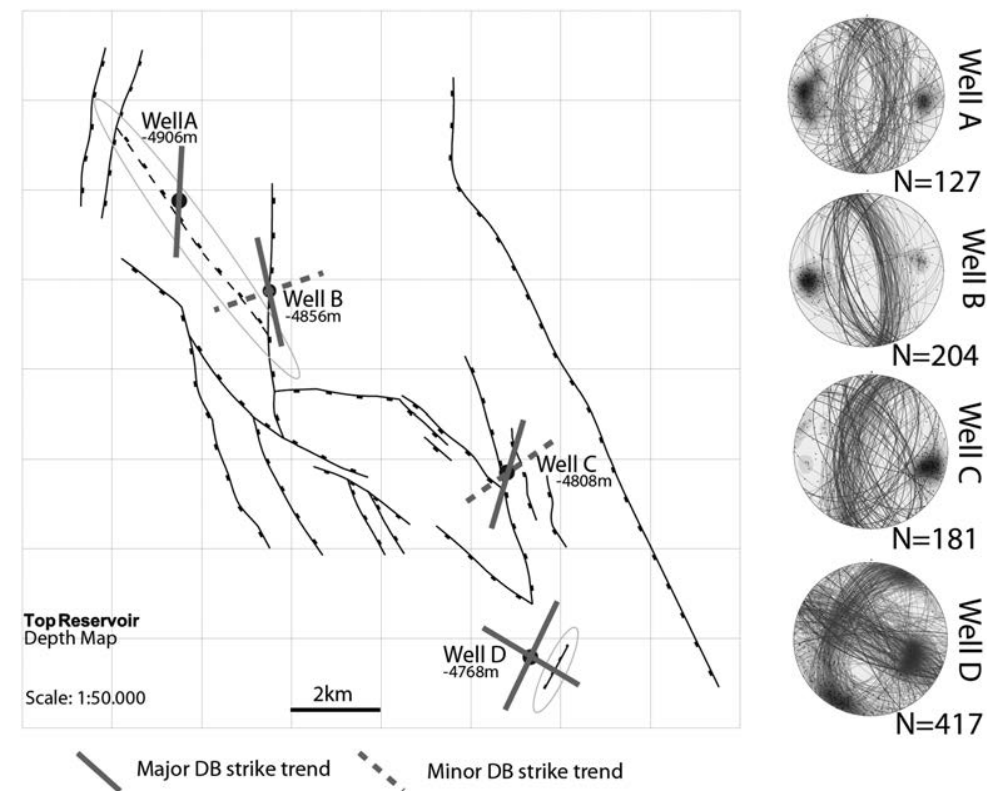

Fig. 11. Structural map of the top of the reservoir. Black lines are normal faults; grey lines on the well locations represent the strike of small scale flow barriers as interpreted on resistivity image logs; dashed lines represent minor strike sets deduced from resistivity image logs. Circles indicate areas that might be reassessed by small scale structural data with a depth resolution. The denoted depths represent the depth of the top of the reservoir unit. Only resistive features (deformation bands) oblique to bedding are visualized in the Schmidt net plots.
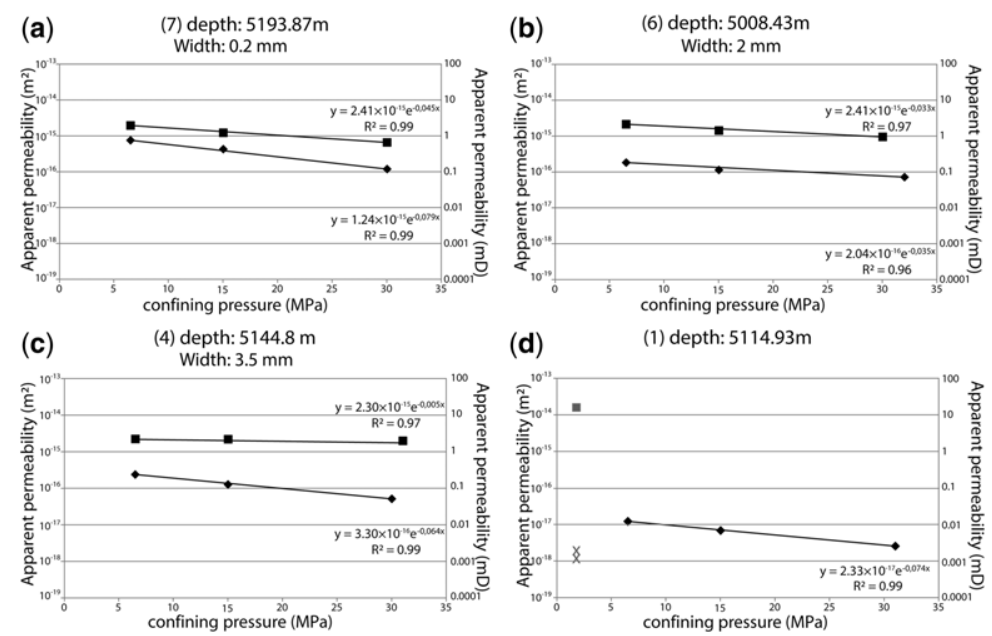

(d)

(1) depth: $5114.93 \mathrm{~m}$

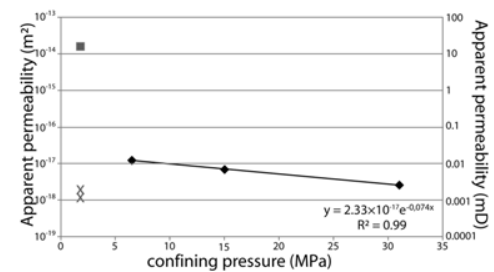

Fig. 12. Apparent permeability results for four pairs of samples (1, 4, 6 and 7). Diamonds are measurements parallel to the bedding of samples that include a deformation band; boxes are samples without a deformation band parallel to bedding. Crosses are measurements perpendicular to bedding. (a) (c) Apparent permeability decreases non linearly. Thin deformation bands (sample 7, a) develop less of an apparent permeability anisotropy than wider deformation bands (sample 4, c). The decrease in apparent permeability correlates with the deformation band width in the three samples where a correlation was possible. (d) The plot for sample 1 visualizes the permeability anisotropy of the regular host rock with samples measured perpendicular to bedding (crosses) as opposed to a measurement parallel to bedding (box). The displayed samples were collected within $10 \mathrm{~cm}$ of the sampling location of sample 1 (black diamonds). The Klinkenberg corrected datapoints (grey boxes and crosses) were measured at a confining pressure of $1.8 \mathrm{MPa}$ and using air as the permeant. 
Table 1. Compilation of transmissibility multiplier (TM) calculations for samples 4, 6 and 7 with different deformation band densities $(D B / m)$

\begin{tabular}{|c|c|c|c|c|c|c|c|c|c|c|c|}
\hline \multirow{2}{*}{\multicolumn{2}{|c|}{$\begin{array}{l}\text { Sample } \\
\text { No. }\end{array}$}} & \multirow{2}{*}{\multicolumn{2}{|c|}{$\begin{array}{l}k_{\mathrm{def}} \\
\left(\mathrm{m}^{2}\right)\end{array}$}} & \multirow{2}{*}{\multicolumn{2}{|c|}{$\begin{array}{l}k_{\text {host }} \\
\left(\mathrm{m}^{2}\right)\end{array}$}} & \multirow{2}{*}{$\begin{array}{l}P_{\text {conf }} \\
\text { (MPa) }\end{array}$} & \multirow{2}{*}{$\begin{array}{c}\mathrm{DB} / \mathrm{m} \\
(N)\end{array}$} & \multirow{2}{*}{$\begin{array}{c}\text { Thickness }(t) \\
(\mathrm{m})\end{array}$} & \multirow[t]{2}{*}{$T M$} & \multicolumn{2}{|c|}{ Leak/seal } \\
\hline & & & & & & & & & & $\begin{array}{l}\text { Geological } \\
\text { timescale }\end{array}$ & $\begin{array}{c}\text { Production } \\
\text { timescale }\end{array}$ \\
\hline A & $\begin{array}{l}4 \\
6 \\
7 \\
\end{array}$ & $\begin{array}{l}4.53 \times 10 \\
2.74 \times 10 \\
9.08 \times 10 \\
\end{array}$ & $\begin{array}{l}18 \\
18 \\
19 \\
\end{array}$ & $\begin{array}{l}1.95 \times 10 \\
2.40 \times 10 \\
6.23 \times 10 \\
\end{array}$ & $\begin{array}{l}15 \\
15 \\
16 \\
\end{array}$ & $\begin{array}{l}30 \\
32 \\
30 \\
\end{array}$ & $\begin{array}{l}1 \\
0.5 \\
0.5 \\
\end{array}$ & $\begin{array}{l}3.50 \times 10^{3} \\
1.50 \times 10^{3} \\
2.00 \times 10^{4} \\
\end{array}$ & $\begin{array}{l}0.002 \\
0.005 \\
0.001\end{array}$ & $\begin{array}{l}\text { Leak } \\
\text { Leak } \\
\text { Leak }\end{array}$ & $\begin{array}{l}\text { Leak } \\
\text { Leak } \\
\text { Leak }\end{array}$ \\
\hline B & $\begin{array}{l}4 \\
6 \\
7\end{array}$ & $\begin{array}{l}4.53 \times 10 \\
2.74 \times 10 \\
9.08 \times 10\end{array}$ & $\begin{array}{l}18 \\
18 \\
19 \\
\end{array}$ & $\begin{array}{l}1.95 \times 10 \\
2.40 \times 10 \\
6.23 \times 10\end{array}$ & $\begin{array}{l}15 \\
15 \\
16 \\
\end{array}$ & $\begin{array}{l}30 \\
32 \\
30\end{array}$ & $\begin{array}{l}100 \\
100 \\
100\end{array}$ & $\begin{array}{l}3.50 \times 10^{3} \\
1.50 \times 10^{3} \\
2.00 \times 10^{4}\end{array}$ & $\begin{array}{l}0.002 \\
0.005 \\
0.001\end{array}$ & $\begin{array}{l}\text { Leak } \\
\text { Leak } \\
\text { Leak }\end{array}$ & $\begin{array}{l}\text { Leak } \\
\text { Leak } \\
\text { Leak }\end{array}$ \\
\hline $\mathrm{C}$ & $\begin{array}{l}4 \\
6 \\
7\end{array}$ & $\begin{array}{l}4.53 \times 10 \\
2.74 \times 10 \\
9.08 \times 10\end{array}$ & $\begin{array}{l}18 \\
18 \\
19\end{array}$ & $\begin{array}{l}1.95 \times 10 \\
2.40 \times 10 \\
6.23 \times 10\end{array}$ & $\begin{array}{l}15 \\
15 \\
16\end{array}$ & $\begin{array}{l}30 \\
32 \\
30\end{array}$ & $\begin{array}{l}17.25 \\
17.25 \\
17.25\end{array}$ & $\begin{array}{l}3.50 \times 10^{3} \\
1.50 \times 10^{3} \\
2.00 \times 10^{4}\end{array}$ & $\begin{array}{l}0.002 \\
0.005 \\
0.001\end{array}$ & $\begin{array}{l}\text { Leak } \\
\text { Leak } \\
\text { Leak }\end{array}$ & $\begin{array}{l}\text { Leak } \\
\text { Leak } \\
\text { Leak }\end{array}$ \\
\hline
\end{tabular}

Input parameters are apparent permeability calculated for the deformation band width and thickness. The length of the reference interval is $20 \mathrm{~m}$. Confining pressures at which apparent permeability has been determined are given.

The experimental observations of Cheung et al. (2012) demonstrate the important role of grain size distribution on the physical properties during the formation of a deformation band. In their experi mental set up, the authors created compaction bands, which are end members of deformation bands with out any considerable shearing. Sandstones that have a comparably narrow grain size distribution (spread below $300 \mu \mathrm{m}$ ) formed localized compaction bands, whereas comparably wide distributions (spread of $700 \mu \mathrm{m})$ resulted in distributed cataclastic flow (Cheung et al. 2012). Our localized cataclastic defor mation bands, however, formed in a host rock with a wide spread of grain size distributions $(>800 \mu \mathrm{m})$ and with shear displacement. Thus, experimental results cannot be transferred to our data with res pect to localization. No consistent trend could be

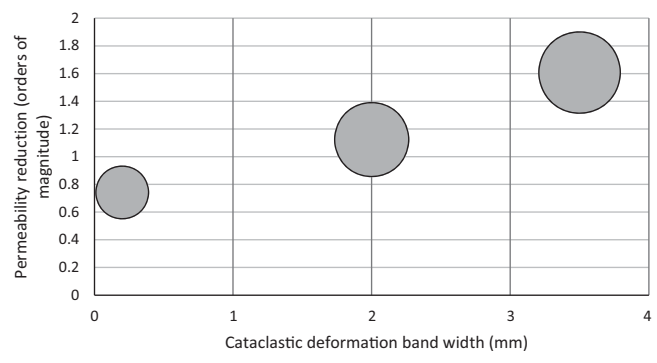

Fig. 13. Apparent permeability across cataclastic deformation bands inferred from deformation band width, based on a combination of grain size v. cataclastic deformation band width correlation plot, and cataclastic deformation band width and apparent permeability reduction plot. The point size corresponds with the grain size. This correlation allows the reservoir quality to be predicted if deformation bands are to be expected in a reservoir unit. established from the width of the grain size distribu tion to the width of the cataclastic deformation bands. Furthermore, no correlation is evident for the deformation band width $v$. the skewness of grain size distributions and the sorting of the host rock (Fig. 5b).

The evolution of deformation bands can well be explained by the localization of stress at load bearing frameworks, which form during initial mechanical and chemical compaction. Small cemented arrays at a high angle to bedding and crossing porous beds may represent such a load bearing framework, with solution along grain boundaries and precipitation in the adjacent pore space (see Figs 2d \& 14). These frameworks may evolve towards a discrete cataclastic deformation band (Fig. 14) due to the overall cementation and strain hardening (Antonellini \& Aydin 1995; Fossen 2010; Ballas et al. 2012; Soliva et al. 2013).

The bedding parallel cementation is mainly con centrated in the finer grained parts of the sand stones, although locally coarser grained layers are also affected (Fig. 3a, d, e). Samples point to a smaller coat coverage in fine grained beds, which results in larger reactive quartz surfaces and causing higher cementation (cf. Bloch et al. 2002).

\section{Data mining}

Data mining, especially marginal plots, proved to be a good method to add a depth resolution to spatial orientation data. The visualization of changes in dip direction and dip with increasing depth cannot be made on a Schmidt net plot.

Given that deformation bands form sub parallel and prior to faults, deformation bands and their ori entation can be used to infer the orientation of 


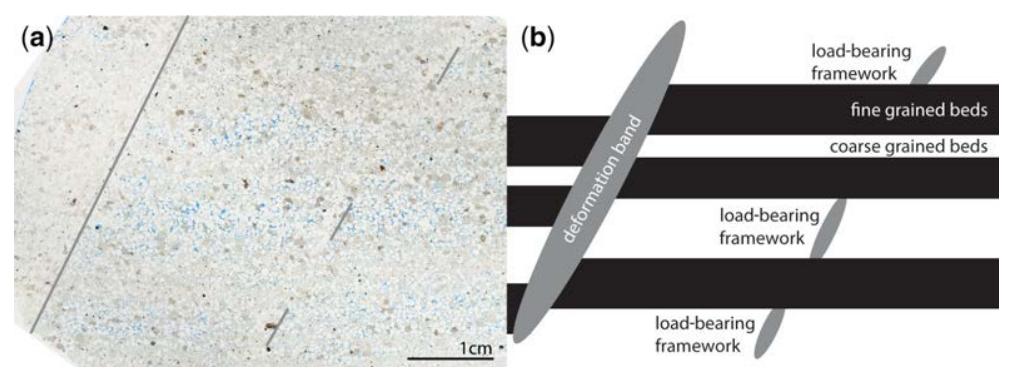

Fig. 14. (a) Thin section of a cataclastic deformation band (grey line) and load bearing structures (dashed line) in the high porosity beds aligned parallel to the deformation band. The image on the right is the same as in Figure $2 \mathrm{~d}$. (b) Conceptual model of the formation of cataclastic deformation bands in high porosity sandstones. The formation of a load bearing framework during chemical compaction acts as a precursor from which a cataclastic deformation band develops. The load bearing framework is developed sub parallel to deformation bands, which supports the hypothesis. Porosity is higher in the coarse grained intervals.

larger scale faults. Thus, faults depicted on seismic lines and inferred from production data may be val idated by faults and deformation bands from the resistivity image logs, and vice versa.

The change in strike and steepening of deforma tion bands with depth in well D may indicate the influence of a flower structure (Woodcock \& Schu bert 1994), although the geometry of the fault planes cannot be visualized with the limited dataset pro vided for this work. The accumulation of a deforma tion band strike in a certain depth interval in well D that is not reflected by seismically observable faults may indicate a subseismically observable fault trend (Fig. 11, circle at well D). The local variations in strike and dip of the deformation bands are ascribed to changes in the local stress field and can be com pared to the interaction of subseismically observ able faults with seismically observable faults (cf. Johansen et al. 2005, fig. 4). The deviation of deformation band strike from seismically observ able fault strike in well $\mathrm{C}$ is attributed to interactions between closely spaced normal faults and is similar to the setting presented in Antonellini \& Aydin (1995, fig. 7).

The resistivity image logs of well A show an absence of subseismically observable faults, defor mation bands and veins matching the strike of a large seismically observable fault on the structural reservoir map. However, several field studies show the occurrence of deformation bands around normal faults (e.g. Antonellini \& Aydin 1995; Johansen \& Fossen 2008; Fossen \& Rotevatn 2012) and their use as a proxy of nearby faults. Such a proxy may, thus, verify reservoir scale faults interpreted from seismic sections (in our case subsalt) or produc tion data. Although deformation bands generally predate fault formation (Antonellini \& Aydin 1995) and are thus not sufficient criteria to infer faults, the mismatch of resistivity and reservoir map data led to a successful revision of the structural map.
Dependencies of deformation band densities in different siliciclastic lithologies could not be estab lished, which may be ascribed to similar lithotypes. However, several field studies clearly demonstrate the accumulation of deformation bands in more competent beds (Schultz \& Fossen 2002). Further more, additional sets of deformation bands related to additional faults in the vicinity of the well affect any regular distribution. An additional factor affect ing deformation band density is the proximity to faults (Antonellini \& Aydin 1995), which is shown to be consistent if the host rock grain size at a sim ilar distance to a fault is the same (Griffiths et al., this volume, in press). The observations by Cheung et al. (2012) also point towards a grain size dis tribution control on the occurrence of compaction bands that might also be applicable to deformation bands with a simple shear component. The number and displacements of observed faults derived from resistivity images could not be linked to different lithotypes due to the one dimensional (1D) data in wells.

Published data from field exposures clearly show an increased number of deformation bands around faults and a correlation with fault displacement (e.g. Antonellini \& Aydin 1995; Rotevatn \& Fossen 2011; Griffiths et al., this volume, in press). Since a well represents an arbitrarily orientated scanline across a fault and surrounding lithotypes in the res ervoir, and the lithotypes are similar, a correlation might be expected. However, well log data show no clear or consistent accumulation of deformation bands either in their occurrence or in the displace ment of small scale faults interpreted from resistiv ity image logs (Fig. 8).

\section{Permeability}

Apparent permeability data of samples, including a cataclastic deformation band and associated 
undisturbed host rock samples, show that the stud ied cataclastic deformation bands have a negative impact on production.

The non linear decrease in apparent permeabil ity with increasing confining pressure is attributed to the closure of microfractures, as well as to gran ular compaction and inelastic pore collapse (cf. Ber nabe 1987; Holt 1994; Fortin et al. 2005; Saillet \& Wibberley 2013). The decrease in permeability with increasing confining pressure as marked by the stress dependency factor, $\gamma$, which is between 0.005 and $0.079 \mathrm{MPa}^{1}$, is within or slightly above that given in literature for sandstones and tight sand stones (Yale 1984 in David et al. 1994; Saillet \& Wibberley 2013).

The maximum reduction of two orders of magni tude for a measured cataclastic deformation band is in the range of previously measured samples (e.g. Fossen \& Bale 2007; Tueckmantel et al. 2012). Experimentally created compaction bands within sandstones led to a permeability reduction of two three orders of magnitude (Vajdova et al. 2004; Baud et al. 2012; Deng et al. 2015). Brittle shear faulting in an experimental set up by Zhu \& Wong (1997) resulted in a permeability decrease of less than one two orders of magnitude compared to the undisturbed rock. Effects of chemical compac tion and dissolution are also considered to have a diverse impact on fluid flow, with stylolites in car bonates showing an unimpeded flow vertically and enhanced flow laterally (Heap et al. 2013). In all our samples, dissolution seams contain clay and are orientated parallel to bedding.

While all our apparent permeability data were measured along bedding and were lower across sheared cataclastic deformation bands, the perme ability reduction is higher across cemented and bimodally distributed bedding and bedding parallel dissolution seams. This corresponds with results of Baud et al. (2012), who reported that compaction bands parallel to bedding would form the most effi cient flow barriers. The application to a field scale, however, needs to include an assessment of the con nectivity of all deformation band types in three dimensions to form extensive barriers to fluid flow (e.g. Fossen \& Bale 2007).

The provided Klinkenberg corrected permeabil ities are not considered for further correlation with the deformation band samples. However, the three samples were taken within $10 \mathrm{~cm}$ of the apparent permeability sample 1 , and are presented to display the anisotropy between fluid flow parallel compared to perpendicular to bedding within the same litho type (Fig. 12d).

The permeability of a sample containing a deformation band is mainly controlled by the lower permeability of the deformation band. Consi dering the entire sample length results in larger permeability coefficients compared to the thin deformation band itself (cf. Main et al. 2000 Baud et al. 2012). As the deformation band will be the controlling factor in the permeability dif ference between samples with and without defor mation bands (cf. Main et al. 2000; Baud et al. 2012), the permeability measurements were also evaluated with regard to the width of the defor mation band. The apparent permeability of the deformation band itself is one (wide cataclastic deformation bands) to two orders (narrow cataclas tic deformation bands) of magnitude lower than the bulk apparent permeability of such host rock sam ples containing a deformation band.

The assessment of the transmissibility multi pliers, calculated with the apparent permeability coefficients of the deformation band, will only sig nificantly change to become sealing if the perme ability anisotropy exceeds more than three orders of magnitude, irrespective of the number of defor mation bands per interval.

A relative permeability reduction after a phase of stress release from 30 to $6.5 \mathrm{MPa}$ was attributed to irreversible granular compaction, which results in permanent deformation (cf. Saillet \& Wibberley 2013) and inelastic pore collapse (Fortin et al. 2005). Although no repeated stress cycles were per formed, the permeability stress hysteresis is highly probable. If a less confined host rock sample after peak confining pressures results in lower permeabil ities than the same sample at high confining pres sures, permeability stress hysteresis as measured in other siliciclastic rocks (e.g. Faulkner \& Rutter 2000) can strongly be inferred.

As several plug samples were (partly) disinte grated after application of confining pressures of up to $32 \mathrm{MPa}$, we suggest that the critical pressure marking the onset of grain crushing and inelas tic pore collapse (e.g. Wong et al. 1997; Tembe et al. 2008) has been exceeded during these mea surements. We suggest that reservoir pore fluid pres sures were very high to maintain host rock stability at the current burial depth. Thus, a significant effec tive stress increase during production could lead to depletion induced compaction failures (cf. Schut jens et al. 2004). Maintaining the initial pore pres sures might be essential in preventing reservoir integrity failures.

Orientation dependent permeability anisotro pies, parallel and perpendicular to bedding, can be attributed to pore shape anisotropies, grain size differences (clay size to sand size), sorting, sedimen tary fabric, compaction, cementation, microcracking and chemical compaction (Benson et al. 2005; Louis et al. 2005; Armitage et al. 2011). The measured reduction corresponds to observed bedding parallel cementation by either quartz or calcite, chemical compaction and bimodal grain size distributions 
on a microscopic scale. Sedimentary fabric induced permeability anisotropies of sandstones of up to four orders of magnitude are in accordance with the findings of Armitage et al. (2011).

\section{Conclusion}

Almost all deformation bands are cataclastic, with the fractures cemented by quartz. Cemented cata clastic fractures are not visible in transmitted light microscopy but can be seen using cathodolumines cence (CL) microscopy. Intersections of dissolution seams and deformation bands indicate that the deformation bands formed prior to and during chemical compaction.

Marginal plots of resistivity log data highlight the rotation of deformation bands and fractures with depth, which may point to flower structures. Data mining from image logs was successfully used to re evaluate structural reservoir maps and seismic scale faults. It may further indicate subseismic fault trends at specific depth intervals. Lithology dependent variations of deformation bands in the reservoir units could not be established from image logs and cores owing to the similar mineralogy of the beds.

A scaling relationship for cataclastic deforma tion bands correlates an increase in deformation band width with an increase in average host rock grain size.

Well cemented and densely packed fine grained host rocks contain thinner deformation bands with a lower apparent permeability contrast of less than one order of magnitude. More porous and coarser grained host rocks reach apparent permeability contrasts of up to two orders of magnitude along bedding. However, the impact of bedding parallel dissolution seams and cementation parallel to fine grained bedding has a larger impact on fluid flow by up to four orders of magnitude.

The failure of some samples at or below $30 \mathrm{MPa}$ confining pressure may be indicative of for mation intervals at high pore fluid pressures that, during reservoir depletion, may lead to depletion induced compaction failure, and hence to reduced flow.

The authors would like to thank RWE DEA AG, Hamburg, for provision of data and the permission to publish the results of this study, as well as for support during the study. We thank Keyvan Osivandi, Nils Buurman, Holger Rieke, Philipp Berger and Robert Lippmann for stimulat ing discussions; Bernhard Krooss and Reinhard Fink are thanked for their contributions to the permeability mea surements. The authors would like to acknowledge the constructive and thorough reviews of Dan Faulkner, an anonymous reviewer and editor Peter Armitage, which sig nificantly improved this manuscript.

\section{References}

Ahmadov, R., Aydin, A., Karimi Fard, M. \& Durlof SKY, L. J. 2007. Permeability upscaling of fault zones in the Aztec Sandstone, Valley of Fire State Park, Nevada, with a focus on slip surfaces and slip bands. Hydrogeology Journal, 15, 12391250.

ANTONELLINI, M. \& AYdin, A. 1994. Effect of faulting on fluid flow in porous sandstones: petrophysical proper ties. American Association of Petroleum Geologists Bulletin, 78, 355377.

Antonellini, M. \& Aydin, A. 1995. Effect of faulting on fluid flow in porous sandstones: geometry and spatial distribution. American Association of Petroleum Geol ogists Bulletin, 79, 642671.

Armitage, P. J., Faulkner, D. R., Worden, R. H Aplin, A. C., Butcher, A. R. \& Iliffe, J. 2011. Experimental measurement of, and controls on, per meability and permeability anisotropy of caprocks from the $\mathrm{CO} 2$ storage project at the Krechba Field, Algeria. Journal of Geophysical Research, 116 , B12208.

Awdal, A., Healy, D. \& Alsop, G. I. 2014. Geometrical analysis of deformation band lozenges and their scal ing relationships to fault lenses. Journal of Structural Geology, 66, 1123.

Ballas, G., Soliva, R., Sizun, J. P., Benedicto, A. Cavailhes, T. \& Raynaud, S. 2012. The importance of the degree of cataclasis in shear bands for fluid flow in porous sandstone, Provence, France. American Association of Petroleum Geologists Bulletin, 96, 21672186.

Baud, P., Meredith, P. \& Townend, E. 2012. Permeabil ity evolution during triaxial compaction of an aniso tropic porous sandstone. Journal of Geophysical Research, 117, B05203.

Benson, P. M., Meredith, P. G., Platzman, E. S. \& White, R. E. 2005. Pore fabric shape anisotropy in porous sandstones and its relation to elastic wave velocity and permeability anisotropy under hydrostatic pressure. International Journal of Rock Mechanics and Mining Sciences, 42, 890899.

BERNABE, Y. 1987. The effective pressure law for perme ability during pore pressure and confining pressure cycling of several crystalline rocks. Journal of Geo physical Research, 92, 649.

Bésuelle, P. \& RudNicki, J. W. 2004. Localization: shear bands and compaction bands. In: GUEGUEN, Y. \& BoutécA, M. (eds) Mechanics of Fluid Saturated Rocks. Elsevier Academic Press, Amster dam, 219321.

Bloch, S., Lander, R. H. \& Bonnell, L. 2002. Anoma lously high porosity and permeability in deeply buried sandstone reservoirs: origin and predictability. Ameri can Association of Petroleum Geologists Bulletin, 86, 301328.

Chemenda, A. I., Wibberley, C. \& Saillet, E. 2012. Evolution of compactive shear deformation bands: numerical models and geological data. Tectonophysics, 526-529, 5666.

Cheung, C. S. N., Baud, P. \& Wong, T. F. 2012. Effect of grain size distribution on the development of compac tion localization in porous sandstone. Geophysical Research Letters, 39, L21302. 
Davatzes, N. C. \& Aydin, A. 2003. Overprinting faulting mechanisms in high porosity sandstones of SE Utah. Journal of Structural Geology, 25, 17951813.

David, C., Wong, T. F., Zhu, W. \& Zhang, J. 1994. Laboratory measurement of compaction induced per meability change in porous rocks: implications for the generation and maintenance of pore pressure excess in the crust. Pure and Applied Geophysics, $\mathbf{1 4 3}, 425456$

David, C., Menendez, B., Zhu, W. \& Wong, T. F. 2001. Mechanical compaction, microstructures and perme ability evolution in sandstones. Physics and Chemistry of the Earth, Part A: Solid Earth and Geodesy, 26, 4551.

Deng, S., Zuo, L., Aydin, A., Dvorkin, J. \& MukerJi, T. 2015. Permeability characterization of natural compac tion bands using core flooding experiments and three dimensional image based analysis: comparing and contrasting the results from two different methods. American Association of Petroleum Geologists Bulle tin, 99, 2749.

EIchHubl, P. \& Flodin, E. 2005. Brittle deformation, fluid flow, and diagenesis in sandstones at Valley of Fire State park, Nevada. In: Pederson, J. \& Dehler, C. M. (eds) Interior Western United States. Geological Society of America, Field Guide, 6, 151167

EichHubl, P., Taylor, W. L., Pollard, D. D. \& Aydin, A. 2004. Paleo fluid flow and deformation in the Aztec Sandstone at the Valley of Fire, Nevada Evidence for the coupling of hydrogeologic, diagenetic, and tectonic processes. Geological Society of America Bulletin, 116, 11201131

EXNER, U., KAISER, J. \& GIER, S. 2013. Deformation bands evolving from dilation to cementation bands in a hydrocarbon reservoir (Vienna Basin, Austria). Marine and Petroleum Geology, 43, 504515.

FAULKNeR, D. R. \& RUTTER, E. H. 2000. Comparisons of water and argon permeability in natural clay bearing fault gouge under high pressure at $20{ }^{\circ} \mathrm{C}$. Journal of Geophysical Research, 105, 1641516426.

Fisher, Q. J. \& KNIPE, R. 2001. Permeability of faults within siliciclastic petroleum reservoirs of the North Sea and Norwegian continental shelf. Marine and Petroleum Geology, 18, 10631081.

Fisher, Q. J., KNIPE, R. J. \& WoRden, R. H. 2000. Micro structures of deformed and non deformed sandstones from the North Sea: implications for the origins of quartz cement in sandstones. In: Worden, R. H. \& Morad, S. (eds) Quartz Cementation in Sandstones. Blackwell Science, Oxford, 129146.

Fortin, J., SChubnel, A. \& GuÉGUen, Y. 2005. Elastic wave velocities and permeability evolution during compaction of Bleurswiller sandstone. International Journal of Rock Mechanics and Mining Sciences, 42 , 873889.

Fossen, H. 2010. Deformation bands formed during soft sediment deformation: observations from SE Utah Marine and Petroleum Geology, 27, 215222.

Fossen, H. \& BALE, A. 2007. Deformation bands and their influence on fluid flow. American Association of Petro leum Geologists Bulletin, 91, 16851700

Fossen, H. \& Rotevatn, A. 2012. Characterization of deformation bands associated with normal and reverse stress states in the Navajo Sandstone, Utah: discussion.
American Association of Petroleum Geologists Bulletin, 96, 869876 .

Fossen, H., SchultZ, R. A., ShiPTon, Z. K. \& Mair, K. 2007. Deformation bands in sandstone: a review. Jour nal of the Geological Society, London, 164, 115.

Fossen, H., Schultz, R. A. \& Torabi, A. 2011. Condi tions and implications for compaction band formation in the Navajo Sandstone, Utah. Journal of Structural Geology, 33, 14771490.

Fowler, C. M., Stead, D., Pandit, B. I., Janser, B. W., Nisbet, E. G. \& Nover, G. 2005. A database of phys ical properties of rocks from the Trans Hudson Oro gen, Canada. Canadian Journal of Earth Sciences, 42, 555572.

Freund, D. \& Nover, G. 1995. Hydrostatic pressure test for the permeability formation factor relation on crys talline rocks from KTB drilling project. Surveys in Geophysics, 16, 4762.

Griffiths, J., Worden, R. H., Faulkner, D. R. \& EDWARDS, A. In press. Deformation band development as a function of intrinsic host rock properties in Trias sic Sherwood Sandstone. In: ARmitage, P. J., Butcher, A. R. ET AL. (eds) Reservoir Quality of Clastic and Carbonate Rocks: Analysis, Modelling and Prediction. Geological Society, London, Special Publications, 435, http://doi.org/10.1144/SP435.11

Guo, J., McCaffrey, K., Jones, R. \& Holdsworth, R. 2009. The spatial heterogeneity of structures in high porosity sandstones: variations and granularity effects in orientation data. Journal of Structural Geology, 31, 628636.

Heap, M. J., Baud, P., Reuschle, T. \& Meredith, P. G. 2013. Stylolites in limestones: barriers to fluid flow? Geology, 42, 5154.

Hildenbrand, A., Schlömer, S. \& Krooss, B. M. 2002. Gas breakthrough experiments on fine grained sedi mentary rocks. Geofluids, 2, 323.

HoLt, R. M. 1994. Effects of coring on petrophysical mea surements. In: International Symposium of the Society of Core Analysts, Stavanger, Norway. Society of Core Analysts, Fredericton, Canada, 7786.

JoHANSEN, T. E. S. \& Fossen, H. 2008. Internal geometry of fault damage zones in interbedded siliciclastic sedi ments. In: Wibberley, C. A. J., Kurz, W., Imber, J., Holdsworth, R. E. \& Collettini, C. (eds) The Inter nal Structure of Fault Zones: Implications for Mechan ical and Fluid Flow Properties. Geological Society, London, Special Publications, 299, 35 56, http:// doi.org/10.1144/SP299.3

Johansen, T. E. S., Fossen, H. \& Kluge, R. 2005. The impact of syn faulting porosity reduction on damage zone architecture in porous sandstone: an outcrop example from the Moab Fault, Utah. Journal of Structural Geology, 27, 14691485.

Jones, F. O. \& OWENS, W. W. 1980. A laboratory study of low permeability gas sands. Journal of Petroleum Technology, 32, 16311640.

KaYSER, A. 2006. Herkunft, Auftreten und Visualisierung von Permeabilitätsbarrieren in einer Gaslagerstätte in Sandsteinen des Rotliegenden (Südliches Perm becken, Deutschland). PhD thesis, Philipps Universität Marburg, Germany.

KLEY, J., FranZKe, H. J. ET AL. 2008. Strain and stress. In: LitTKe, R., Bayer, U., Gajewski, D. \& Nelskamp, S. 
(eds) Dynamics of Complex Intracontinental Basins The Central European Basin System. Springer, Berlin, 97124.

Kolyukhin, D., Schueller, S., Espedal, M. S. \& Fossen, H. 2009. Deformation band populations in fault damage zone impact on fluid flow. Computa tional Geosciences, 14, 231248.

Legler, B. \& Marchel, C. 2008. Deformation bands in Permian reservoir sandstones (Rotliegend, North west Germany). Freiberger Forschungshefte, C528, 125138.

LOHR, T., KraWCZYK, C. M. ET AL. 2007. Strain partition ing due to salt: insights from interpretation of a 3D seis mic data set in the NW German Basin. Basin Research, 19, 579597

Louis, L., David, C., Metz, V., Robion, P., Menéndez, B. \& Kissel, C. 2005. Microstructural control on the anisotropy of elastic and transport properties in unde formed sandstones. International Journal of Rock Mechanics and Mining Sciences, 42, 911923.

Main, I. G., Kwon, O., Ngwenya, B. T. \& Elphick, S. C. 2000. Fault sealing during deformation band growth in porous sandstone. Geology, 28, 11311134.

Manzocchi, T., Walsh, J. J., Nell, P. \& Yielding, G. 1999. Fault transmissibility multipliers for flow simu lation models. Petroleum Geoscience, 5, 53 63, http://doi.org/10.1144/petgeo.5.1.53

Menning, M. 1995. A numerical time scale for the Perm ian and Triassic periods: an integrated time analysis In: Scholle, P. A., Peryt, T. M. \& Ulmer Scholle, D. S. (eds) The Permian of Northern Pangea, Vol ume 1: Paleogeography, Paleoclimates, Stratigraphy. Springer, Berlin, 7797.

Nicol, A., Childs, C., Walsh, J. J. \& Schafer, K. W. 2013. A geometric model for the formation of deforma tion band clusters. Journal of Structural Geology, $\mathbf{5 5}$, 2133.

Ogilvie, S. R. \& Glover, P. W. J. 2001. The petrophysical properties of deformation bands in relation to their microstructure. Earth and Planetary Science Letters, 193, 123142

Olsson, W. A., Lorenz, J. C. \& Cooper, S. P. 2004. A mechanical model for multiply oriented conjugate deformation bands. Journal of Structural Geology, 26, 325338

Parry, W. T., Chan, M. A. \& Beitler, B. 2004. Chemical bleaching indicates episodes of fluid flow in deforma tion bands in sandstone. American Association of Petroleum Geologists Bulletin, 88, 175191.

Rotevatn, A. \& Fossen, H. 2011. Simulating the effect of subseismic fault tails and process zones in a siliciclas tic reservoir analogue: implications for aquifer support and trap definition. Marine and Petroleum Geology, 28, 16481662.

Rotevatn, A., Fossen, H., Hesthammer, J., Aas, T. E. \& Howell, J. A. 2007. Are relay ramps conduits for fluid flow? Structural analysis of a relay ramp in Arches National Park, Utah. In: Lonergan, L., Jolly, R. J. H., Rawnsley, K. \& SAnderson, D. J. (eds) Fractured Reservoirs. Geological Society, London, Special Publications, 270, 55 71, http://doi.org/10. 1144/GSL.SP.2007.270.01.04

Saillet, E. \& Wibberley, C. A. J. 2013. Permeability and flow impact of faults and deformation bands in high porosity sand reservoirs: southeast Basin, France, analog. American Association of Petroleum Geologists Bulletin, 97, 437464.

SCHÖNER, R. 2006. Comparison of Rotliegend sand stone diagenesis from the northern and southern margin of the North German Basin, and implications for the importance of organic maturation and migra tion. $\mathrm{PhD}$ thesis, Friedrich Schiller Universität Jena Germany.

Schueller, S., Braathen, A., Fossen, H. \& Tver ANGER, J. 2013. Spatial distribution of deformation bands in damage zones of extensional faults in porous sandstones: statistical analysis of field data. Journal of Structural Geology, 52, 148162.

Schultz, R. A. \& Fossen, H. 2002. Displacement length scaling in three dimensions: the importance of aspect ratio and application to deformation bands. Journal of Structural Geology, 24, 13891411.

Schultz, R. A., Soliva, R., Fossen, H., OKubo, C. H. \& ReEves, D. M. 2008. Dependence of displacement length scaling relations for fractures and deformation bands on the volumetric changes across them. Journal of Structural Geology, 30, 14051411.

Schultz, R. A., OKubo, C. H. \& Fossen, H. 2010. Poros ity and grain size controls on compaction band forma tion in Jurassic Navajo Sandstone. Geophysical Research Letters, 37, 15.

Schultz, R. A., Klimczak, C., Fossen, H., Olson, J. E., Exner, U., Reeves, D. M. \& Soliva, R. 2013. Statistical tests of scaling relationships for geo logic structures. Journal of Structural Geology, 48, 8594.

Schutjens, P. M. T. M., Hanssen, T. H., Hettema, M. H. H., Merour, J., De Bree, P., Coremans, J. W. A. \& Helliesen, G. 2004. Compaction induced porosity/permeability reduction in sandstone reser voirs: data and model for elasticity dominated defor mation. SPE Reservoir Evaluation \& Engineering, 7 , 202216.

Shipton, Z. K., Evans, J. P. \& Thompson, L. B. 2005. The geometry and thickness of deformation band fault core and its influence on sealing characteristics of deformation band fault zones. In: SorKHABI, R. \& TsujI, Y. (eds) Faults, Fluid Flow, and Petroleum Traps. American Association of Petroleum Geologists, Memoirs, 85, 181195.

Soliva, R., Schultz, R. A., Ballas, G., Taboada, A., Wibberley, C., Saillet, E. \& Benedicto, A 2013. A model of strain localization in porous sand stone as a function of tectonic setting, burial and material properties; new insight from Provence (southern France). Journal of Structural Geology, 49, 5063.

SternloF, K. R. 2006. Structural geology, propaga tion mechanics and hydraulic effects of compaction bands in sandstone. PhD thesis, Stanford University, CA.

Tembe, S., Baud, P. \& Wong, T. F. 2008. Stress conditions for the propagation of discrete compaction bands in porous sandstone. Journal of Geophysical Research, 113, 116.

TorABI, A. 2014. Cataclastic bands in immature and poorly lithified sandstone, examples from Corsica, France. Tectonophysics, 630, 91102. 
Tueckmantel, C., Fisher, Q. J., Grattoni, C. A. \& Aplin, A. C. 2012. Single and two phase fluid flow properties of cataclastic fault rocks in porous sand stone. Marine and Petroleum Geology, 29, 129142.

VACKINER, A. A. 2011. Sedimentary facies reconstruction and kinematic restoration of an Upper Permian tight gas field, north western Germany. $\mathrm{PhD}$ thesis, RWTH Aachen University, Germany.

Vajdova, V., Baud, P. \& Wong, T. F. 2004. Permeability evolution during localized deformation in Bentheim sandstone. Journal of Geophysical Research, 109, 115.

Wennberg, O. P., Casini, G., Jahanpanah, A., Lapponi, F., Ineson, J., Wall, B. G. \& Gillespie, P. 2013. Deformation bands in chalk, examples from the
Shetland Group of the Oseberg Field, North Sea, Norway. Journal of Structural Geology, 56, 103117. Williams, G. J. 2011. Data Mining with R and Rattle: The Art of Excavating Data for Knowledge Discovery. Springer, New York

Wong, T. F., DAvid, C. \& ZHU, W. 1997. The transition from brittle faulting to cataclastic flow in porous sand stones: mechanical deformation. Journal of Geophysi cal Research, 102, 30093025.

Woodcock, N. H. \& Schubert, C. 1994. Continental strike slip tectonics. In: HaNCOCK, P. (ed.) Continental Deformation. Pergamon Press, Oxford, 251263.

Zhu, C. \& Wong, T. F. 1997. The transition from brittle faulting to cataclastic flow: permeability evolution. Journal of Geophysical Research, 102, 30273041. 
Karlsruher Institut für Technologie

\section{Repository KITopen}

Dies ist ein Postprint/begutachtetes Manuskript.

Empfohlene Zitierung:

Busch, B.; Winkler, R.; Osivandi, K.; Nover, G.; Amann-Hildenbrand, A.; Hilgers, C. Evolution of small-scale flow barriers in German Rotliegend siliciclastics. 2015. Special publications / the Geological Society, London, 435.

doi: $10.5445 / / R / 1000054662$

Zitierung der Originalveröffentlichung:

Busch, B.; Winkler, R.; Osivandi, K.; Nover, G.; Amann-Hildenbrand, A.; Hilgers, C. Evolution of small-scale flow barriers in German Rotliegend siliciclastics. 2015. Special publications / the Geological Society, London, 435 (141-160), online. doi:10.1144/SP435.3 